\title{
Changes in thermal and precipitation conditions in Poland in 1971-2010
}

\author{
BARBARA SKOWERA ${ }^{1}$, JOANNA KOPCIŃSKA², BOGUMIŁA KOPEĆ ${ }^{1}$ \\ ${ }^{1}$ Department of Ecology, Climatology and Air Protection, ${ }^{2}$ Department of Applied Mathematics \\ University of Agriculture in Kraków
}

\begin{abstract}
Changes in thermal and precipitation conditions in Poland in 1971-2010. The article presents changes in thermal and precipitation conditions on Polish territory in the years 1971-2010 based on data from six meteorological stations (Koszalin, Olsztyn, Poznań, Lublin, Opole and Kraków). These data concern the monthly average air temperature, precipitation and the number of days with precipitation per month. Based on the analysis of changing trends in the study of meteorological elements, authors observed an increase in the mean annual air temperature of about $0.9^{\circ} \mathrm{C}$ over 10 years in all localities. In contrast, trends in the average monthly air temperatures were characterised by temporal and spatial variation. As a result of the increase in temperature, there was a change in the dates signifying the beginning and the end of the thermal periods: farming $(\mathrm{OG})$, vegetation $(\mathrm{OW})$, intensive vegetation (OIW) and maturation or thermal summers $(\mathrm{OD} / \mathrm{L})$. A tendency for these periods to start earlier was noted. Statistically significant changes were found for the following periods: vegetation in Koszalin and Olsztyn, intensive vegetation at all stations and thermal summer only in Lublin. An increasingly later end to these periods was noted, and statistically significant trends were found for the dates of the end of the following periods: maturation (thermal summer) at all stations except Opole, intensive vegetation in Poznań and Lublin and vegetation in Lublin and Opole. Seasonal and monthly precipitation totals in the years 1971-2010 were characterised by cyclicality. Significant upward
\end{abstract}

trends were found only in the case of monthly precipitation totals in August in Koszalin and the sum of precipitation in the cooler half of the year in Poznań. In contrast, there was more days with precipitation at all stations included in the study, but the statistical significance of trends varied by location. Changes in thermal and precipitation conditions were accompanied by, among other factors, an increase in temperature, changes in the length of thermal periods and an increase in the frequency of rainfall. All of this is important information for the agricultural sector regarding changing crop conditions.

Key words: precipitation, number of days with precipitation, temperature, thermal seasons, trends

\section{INTRODUCTION}

The global rise of air temperature that was observed in the XX century is the reason behind regional agro-climatic effects (Ustrnul and Czekierda 2007, Żmudzka 2009, Górski and Kozyra 2011, Michalska 2011).

The increase in air temperature is accompanied, among other factors, by an increase in potential evaporation and consequently affects the water needs of crops, the amount of sunshine in the spring-summer period and changes their thermal stages (Olszewski and Żmudzka 
2000, Żmudzka and Dobrowolska 2001, Kołodziej et al. 2003, Kołodziej and Węgrzyn 2004, Żmudzka 2004, Bański and Błażejczyk 2005, Olechnowicz-Bobrowska and Wojkowski 2006, Bartoszek and Banasiewicz 2007, Skowera and Kopeć 2008, Banaszkiewicz et al. 2009). Previous studies of the rain regime in Poland showed no significant changes. Czarnecka and Nidzgorska-Lencewicz (2012) found in most parts of the country a small, non-significant upward trend in precipitation in the spring and autumn and a decrease in the sum in summer and winter. They also noted changes in rainfall patterns and a declining share of summer precipitation in the total annual sum (Kożuchowski and Degirmendžić 2005, Bochenek et al. 2012).

Expanding our knowledge of the changes in thermal and precipitation conditions characterising spatial and temporal dynamics is particularly important in the context of plant cultivation. Thus, the aim of this study was a quantitative assessment of thermal and precipitation changes (including air temperature, precipitation totals, the number of days with precipitation and thermal periods) in Poland in the years 1971-2010.

\section{MATERIAL AND METHODS}

In this study authors used the monthly mean air temperature, the monthly sum and the number of days with precipitation greater than $0.1 \mathrm{~mm}$ taken from six meteorological stations of the IMGW network in the years 1971-2010. These meteorological stations were located in Koszalin, Olsztyn, Poznań, Lublin, Opole and Kraków.
The increasing or decreasing trends of the mean monthly and annual air temperature in the forty-year period were examined at the beginning of this study. Using the Mann-Kendall test, the null hypothesis of no trend, i.e. the observations (monthly and annual air temperatures in 1971-2010) were randomly ordered in time, was tested against the alternative hypothesis, where the mean length was an increasing or decreasing monotonic trend (Hirsh et al. 1982). The presence of a statistically significant trend was evaluated using the $Z$ value statistic. A positive (negative) value of $Z$ indicated an upward (downward) trend. The null hypothesis of no trend was rejected on the significance level $\alpha=0.05$. If a significant trend was found, the rate of change (monthly and annual air temperature) was calculated, using the Sen slope estimator (Hirsh et al. 1982).

The next step of the research was to count the dates of the beginning and the end of the thermal seasons important to plant cultivation, such as: farming - OG $\left(\mathrm{t}>3^{\circ} \mathrm{C}\right)$, vegetation $-\mathrm{OW}\left(\mathrm{t}>5^{\circ} \mathrm{C}\right)$, intensive of plant growth - OIW $\left(\mathrm{t}>10^{\circ} \mathrm{C}\right)$ and maturation season (i.e. the thermal summer $)-\mathrm{OD} / \mathrm{L}\left(\mathrm{t}>15^{\circ} \mathrm{C}\right)$ in each of the examined years. The monotonous trend of dates of the beginning and the end of each of the thermal seasons was also recorded.

The precipitation aspect was characterised by two elements: the sum of the precipitation and the number of days with precipitation more than $0.1 \mathrm{~mm}$. The monotonous trend was checked and the increase of the sum of the monthly, seasonal and annual precipitation and the number of days with precipitation were estimated. 
The decade average of thermal season duration (OG, OW, OIW, OD/L), seasonal sum of precipitation and number of days with precipitation were calculated.

\section{RESULTS AND DISCUSSION}

\section{Thermal conditions}

Based on the mean monthly temperature of Koszalin, Olsztyn, Poznań, Lublin and Opole, the trend of changes of air temperature were recorded. A statistically significant upward trend of the mean annual air temperature appeared at examined stations. However, the significant monthly air temperature trend was found only in several months of the warm season of the year, i.e. April, July and August (in all of the tested meteorological stations). In June a significant trend was found in the south and south-east of Poland (Opole, Lublin), but in September a significant change was only found in the north of Poland (Koszalin). In May there were not observed any statistically significant air temperature trends. The values of the Mann-Kendall statistics $Z$ are presented in Table 1 .
The increase of the mean annual air temperature in all examined stations reached approximately $0.9^{\circ} \mathrm{C}$ over 10 years. In the months of the warm season of the year (from April to September), for which an upward trend was calculated, the increase of the mean air temperature varied from 0.3 to $0.8^{\circ} \mathrm{C}$ over 10 years. In the vegetation season, the rise of temperature ranged from 0.6 to $0.8^{\circ} \mathrm{C}$ in April, 0.4 to $0.6^{\circ} \mathrm{C}$ in June, 0.6 to $0.8^{\circ} \mathrm{C}$ in July and 0.4 to $0.5^{\circ} \mathrm{C}$ in August. In September a statistically significant rise of air temperature was observed only in Koszalin $\left(0.4^{\circ} \mathrm{C}\right.$ over 10 years $)$.

The upward or downward trend of the air temperature implied changes in the date of the beginning and end of the thermal seasons and their length. In 1971-2010 the tendency for an earlier beginning of farming (OG), vegetation (OW), intensive vegetation (OIW) and ripening, i.e. thermal summer seasons (OD/L), were confirmed (Table 2).

This trend was observed in all of the meteorological stations, however, a significant change of the date of the beginning of the thermal seasons was

TABLE 1. Trends of mean temperature during warm half of year (1971-2010). The values of the standardized Mann-Kendall statistics $(Z)$

\begin{tabular}{|l|c|c|c|c|c|c|c|}
\hline $\begin{array}{l}\text { Meteorological } \\
\text { station }\end{array}$ & $\begin{array}{c}\text { January- } \\
- \text { December }\end{array}$ & April & May & June & July & August & September \\
\hline Koszalin & $3.55^{*}$ & $4.19^{*}$ & 0.73 & 1.58 & $2.41^{*}$ & $2.56^{*}$ & $2.31^{*}$ \\
\hline Olsztyn & $2.42^{*}$ & $3.61^{*}$ & 0.01 & 1.59 & $2.68^{*}$ & $2.31^{*}$ & 1.77 \\
\hline Poznań & $2.85^{*}$ & $4.79^{*}$ & 1.58 & 1.85 & $2.28^{*}$ & $2.27^{*}$ & 1.46 \\
\hline Lublin & $2.74^{*}$ & $2.97^{*}$ & 0.79 & $2.50^{*}$ & $3.26^{*}$ & $3.41^{*}$ & 0.21 \\
\hline Opole & $2.61^{*}$ & $3.50^{*}$ & 1.29 & $2.72^{*}$ & $3.32^{*}$ & $2.60^{*}$ & 0.84 \\
\hline Kraków & $3.24^{*}$ & $3.22^{*}$ & 1.82 & $3.52^{*}$ & $3.62^{*}$ & $3.28^{*}$ & 1.08 \\
\hline
\end{tabular}

*The values indicate the statistically significant trend on the $\alpha=0.05$ level of significance $(|\mathrm{Z}|>1.95)$. Some of the calculated values indicate the significant trend on the $\alpha=0.1$ level of significance $(|\mathrm{Z}|>1.28)$. 
TABLE 2. Trends of dates of the beginning and the end of the thermal stages (1971-2010). The values of the standardized Mann-Kendall statistics $(Z)$

\begin{tabular}{|l|c|c|c|c|c|c|c|c|}
\hline $\begin{array}{l}\text { Meteorological } \\
\text { station }\end{array}$ & $\mathrm{t} \geq 3^{\circ} \mathrm{C}$ & $\mathrm{t} \geq 5^{\circ} \mathrm{C}$ & $\mathrm{t} \geq 10^{\circ} \mathrm{C}$ & $\mathrm{t} \geq 15^{\circ} \mathrm{C}$ & $\mathrm{t} \leq 15^{\circ} \mathrm{C}$ & $\mathrm{t} \leq 10^{\circ} \mathrm{C}$ & $\mathrm{t} \leq 5^{\circ} \mathrm{C}$ & $\mathrm{t} \leq 3^{\circ} \mathrm{C}$ \\
\hline Koszalin & -1.69 & $-3.20^{*}$ & $-2.24^{*}$ & -1.82 & $3.00^{*}$ & 1.66 & 1.52 & 0.82 \\
\hline Olsztyn & -0.61 & $-3.07^{*}$ & $-2.30^{*}$ & -1.36 & $2.58^{*}$ & 1.94 & 0.98 & 1.01 \\
\hline Poznań & -0.19 & -1.18 & $-3.93^{*}$ & -1.04 & $2.28^{*}$ & $1.64^{*}$ & 1.24 & 0.76 \\
\hline Lublin & 0.07 & -1.35 & $-2.94^{*}$ & $-1.99^{*}$ & $2.77^{*}$ & $2.18^{*}$ & $2.21^{*}$ & 1.61 \\
\hline Opole & -0.58 & 0.02 & $-3.50^{*}$ & -1.47 & 1.51 & 1.65 & $2.33^{*}$ & 0.58 \\
\hline Kraków & -1.04 & -0.92 & $-3.81^{*}$ & -1.66 & $3.09^{*}$ & $2.41^{*}$ & $2.27^{*}$ & 1.21 \\
\hline
\end{tabular}

*The values indicate the statistically significant trend on the $\alpha=0.05$ level of significance $(|Z|>1.95)$. Some of the calculated values indicate the significant trend on the $\alpha=0.1$ level of significance $(|\mathrm{Z}|>1.28)$.

diversified over the area of Poland. There was a statistically significant change confirmed of the beginning of the vegetation season in Koszalin and in Olsztyn, an earlier beginning of the intensive vegetation season at all stations and an earlier beginning of the thermal summer only in Lublin.

The end of the thermal seasons behaved in a different way. All of these periods ended later, however, a statistically significant upward trends were confirmed only for the summer in Koszalin, Olsztyn, Poznań and Lublin. The later dates of the end of the intensive vegetation seasons in Lublin and the vegetation stages in Lublin and Opole were statistically proved.

A consequence of the earlier dates of the beginning and the later dates of the end of the thermal seasons was an extension of the periods of all of the thermal seasons in 1971-2010. However, the lengths of these seasons were diversified in all of the examined stations. The farming season extended from 10 days in Olsztyn to 22 days in Koszalin, the vegetation season extended from 12 days in
Poznań to 20 days in Koszalin, whereas the intensive vegetation season extended from 13 days in Olsztyn to 28 days in Poznań (Fig. 1).

\section{Precipitation}

The rise of potential evapotranspiration, which causes an increase in plant water needs, is a consequence of changes in air temperature. That is the reason why the precipitation (sum and number of days with precipitation) was examined.

A significant trend in changing sums of monthly precipitation was noticed only in Koszalin in August out of the analysed stations, with a value of $13 \mathrm{~mm}$ over 10 years. Whereas a significant trend of the sum of seasonal precipitation was observed only in Poznan in the cool half of the year. Its value was $20 \mathrm{~mm}$ over 10 years.

As far as the number of days with precipitation was concerned in comparison to the sum of precipitation, a significant change in this element was noticed in all of the studied stations taken into account in this study (Table 3, Fig. 2). The values of the Mann-Kendall statistics were 
Koszalin

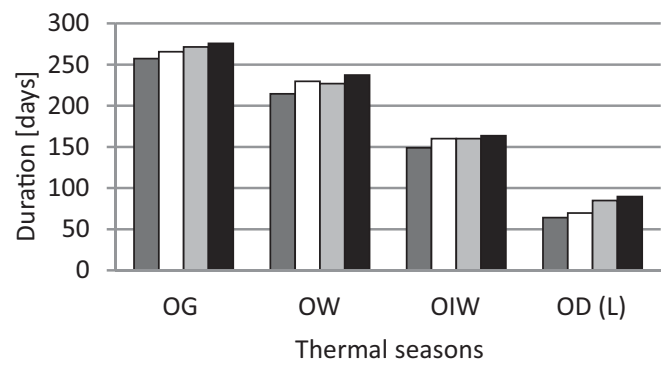

Poznań

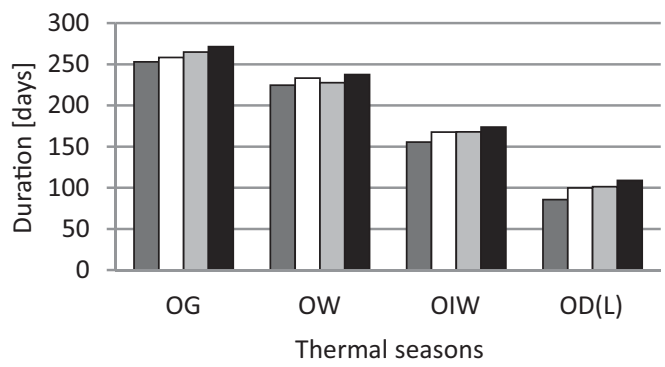

Opole

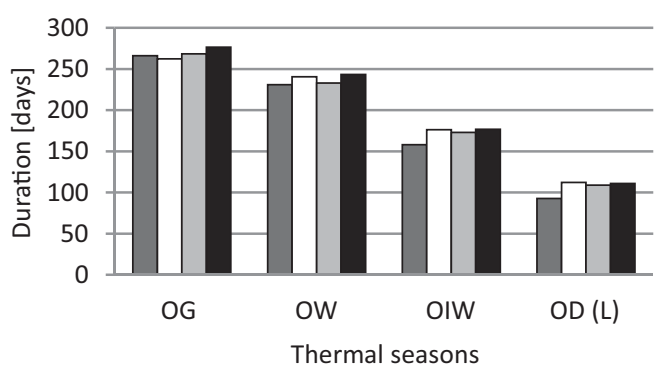

Olsztyn

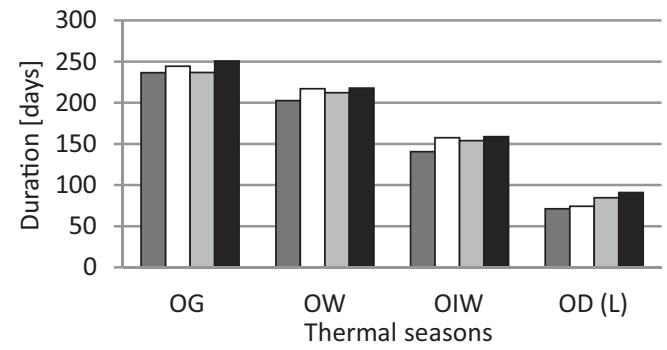

Lublin

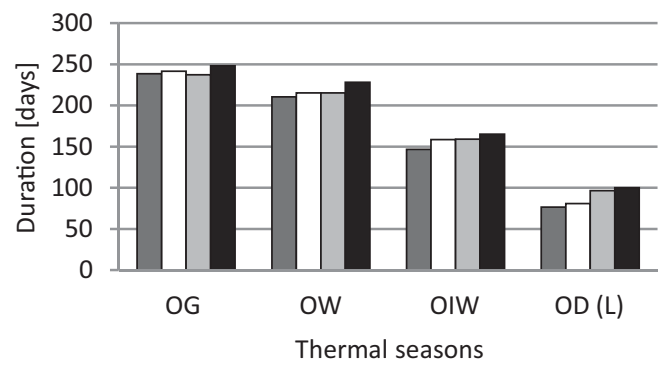

Kraków

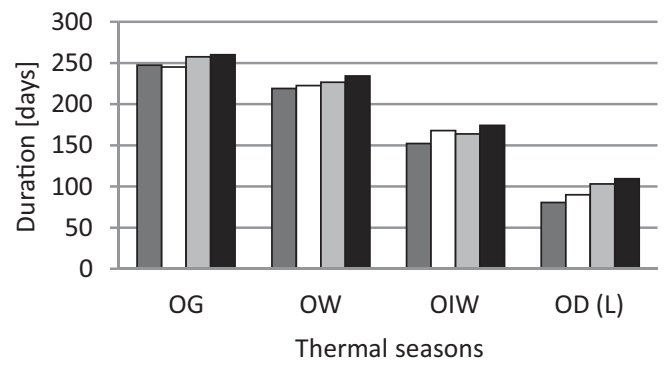

1971-1980

$1981-1990$

1991-2000

2001-2010

FIGURE 1. Duration of thermal seasons in following decades (1971-2010): OG - farming season, OW

- vegetation season, OIW - season of intensive plant vegetation, OD (L) - summer season 
TABLE 3. Trends of the number of days with precipitation (1971--2010). The values of the standardized Mann-Kendall statistics $(Z)$

\begin{tabular}{|l|c|c|c|c|c|c|c|c|c|}
\hline $\begin{array}{l}\text { Meteorological } \\
\text { station }\end{array}$ & $\begin{array}{c}\text { Janu- } \\
\text { ary-De- } \\
\text { cember }\end{array}$ & $\begin{array}{c}\text { April- } \\
- \text { Sep- } \\
\text { tember }\end{array}$ & $\begin{array}{c}\text { Octo- } \\
\text { ber- } \\
\text {-March }\end{array}$ & April & May & June & July & $\begin{array}{c}\text { Au- } \\
\text { gust }\end{array}$ & $\begin{array}{c}\text { Septem- } \\
\text { ber }\end{array}$ \\
\hline Koszalin & $5.66^{*}$ & $4.80^{*}$ & $5.06^{*}$ & $2.31^{*}$ & $3.51^{*}$ & $2.31^{*}$ & 1.71 & $3.16^{*}$ & 1.16 \\
\hline Olsztyn & $5.72^{*}$ & $4.11^{*}$ & $5.69^{*}$ & $2.16^{*}$ & $4.14^{*}$ & $1.99^{*}$ & 1.79 & $2.68^{*}$ & 0.69 \\
\hline Poznań & $5.52^{*}$ & $4.14^{*}$ & $4.56^{*}$ & 1.51 & $2.70^{*}$ & 0.99 & 1.49 & $2.18^{*}$ & $2.26^{*}$ \\
\hline Lublin & $5.94^{*}$ & $3.95^{*}$ & -0.01 & $2.45^{*}$ & $2.17^{*}$ & $2.17^{*}$ & $2.40^{*}$ & $2.23^{*}$ & 0.55 \\
\hline Opole & $5.29^{*}$ & $3.15^{*}$ & -0.01 & 1.08 & 1.95 & 0.57 & 1.14 & $2.12^{*}$ & 0.40 \\
\hline Kraków & $6.20^{*}$ & $3.75^{*}$ & $5.90^{*}$ & 1.78 & $3.65^{*}$ & 1.03 & $2.55^{*}$ & 1.95 & 1.44 \\
\hline
\end{tabular}

*The values indicate the statistically significant trend on the $\alpha=0.05$ level of significance $(|Z|>1.95)$. Some of the calculated values indicate the significant trend on the $\alpha=0.1$ level of significance $(|\mathrm{Z}|>1.28)$.

diversified in the studied period and in the examined stations. The statistically significant values of the number of days with precipitation above $0.1 \mathrm{~mm}$ for the warm and cool half of the year and for each month of the warm half of the year are presented in Table 3.

A significant upward trend of the number of days with precipitation was only observed in the entire year and in the warm half of the year. Whereas in the cool half of the year, a significant upward trend appeared only in four stations and the number of days with precipitation increased from 12 to 14 days over 10 years (Table 3 ). However, in the warm half of the year, the increased number of days with precipitation was lower and varied from 4 days per 10 years in Opole to 8 days per 10 years in Koszalin (Fig. 2).

A significant trend in the change of the number of days with precipitation in the following months of the year was noticed only in the warm half of the year. However, in all of the studied stations a significant trend was only noticed in May and in August. In the other months of the year, a significant trend of the number of days with precipitation was diversified in all of the examined stations (Table 3). The monthly increase of the number of days with precipitation in the warm half of the year varied from 1.2 to 2.4 days over 10 years.

The results presented in this paper, concerning the consequence of a rise in the air temperature, coincide with the conclusions of other studies of various aspects of climate change in the area of Poland and the tendency of a global change in air temperature (Kożuchowski and Degirmendžić 2005, Żmudzka 2009, 2012, Michalska 2011). These changes are clearly visible, especially from the end of the 1980s. The warmest decade began in 2000 in comparison to the previous decades (Kundzewicz and Juda-Rezler 2010, Kundzewicz and Kędziora 2010).

The results concerning the changes of the dates of the beginning, the end and the duration of the thermal seasons coincide with the results of Kożuchowski and Degirmendžić (2005), who compared the periods 1951-2000 and 1991-2000 using data from five meteorological stations: Szczecin, Wrocław, Łódź, Suwałki 
Koszalin

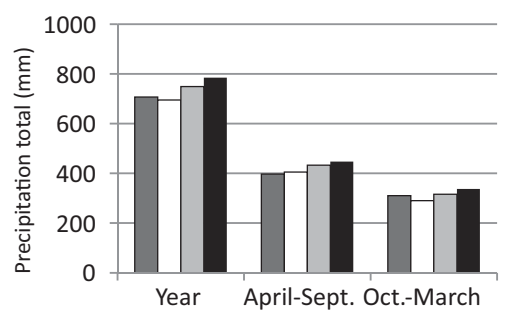

Olsztyn

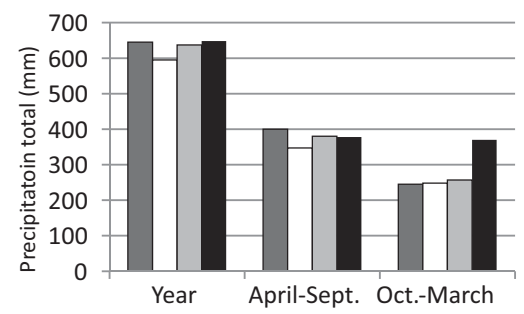

Poznań

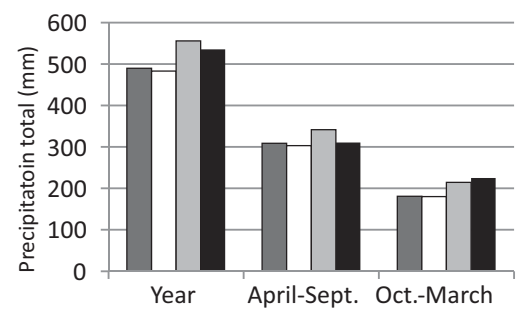

Lublin

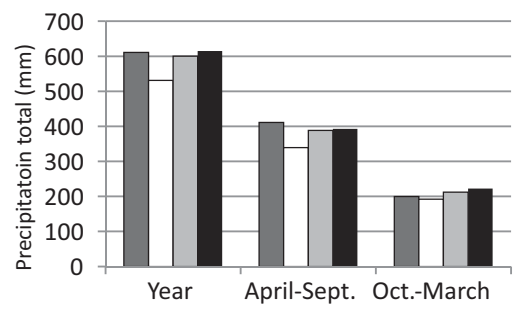

Opole

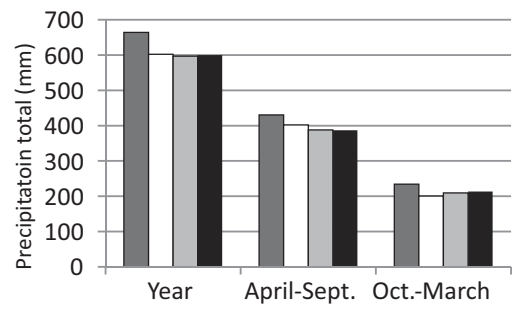

Kraków-Balice

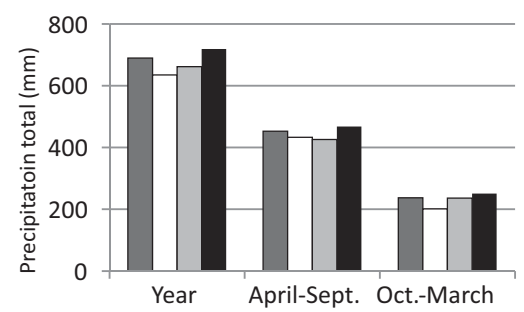

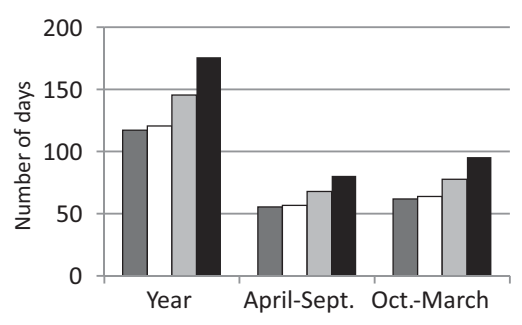
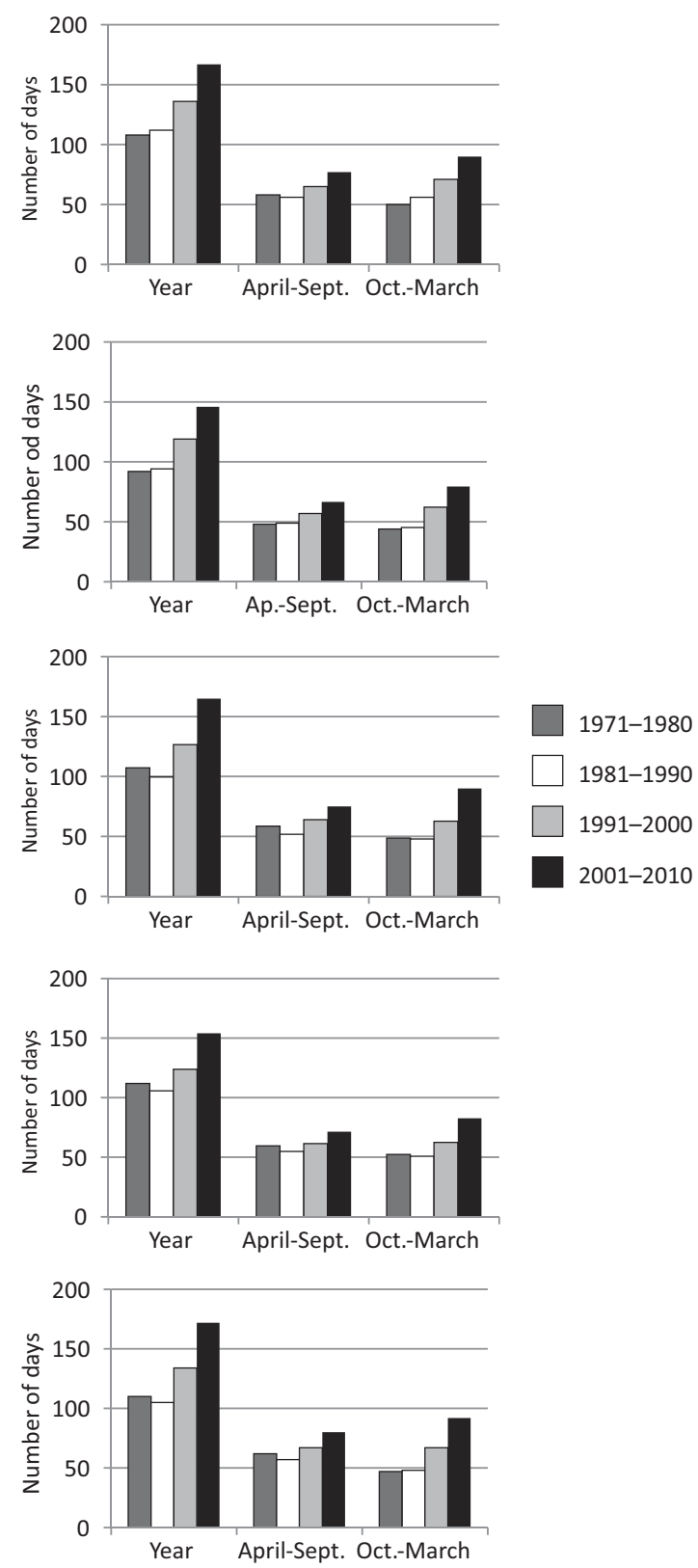

FIGURE 2. The sum of precipitation and the number of days with precipitation in following decades (1971-2010) 
and Przemyśl. They confirmed the earlier beginning of the vegetation season in 1991-2000, but a statistically significant trend of the change of the beginning of these seasons was observed in Szczecin and Wrocław, and a significant trend of the end of this period was noticed in Wrocław and Łódź. The thermal summer lasted longer throughout the whole decade in all meteorological stations and varied from 5 days longer in Przemyśl to 10 days longer in Wrocław.

In this paper authors noted that the dates of the beginning of the vegetation season $(\mathrm{OW})$ and of the intensive vegetation season (OIW) indicated a larger variability in comparison to the dates of their end. The extension of the duration of the thermal seasons was caused more by the earlier dates of the beginning than their end. It is possible to explain the diversification of the beginning and the end of the thermal seasons by the increase of the advection air from the west in the first half of the year (Ustrnul and Czekierda 2007).

Research on the precipitation did not show statistically significant changes, and only the characteristic changeability connected with atmospheric circulation was observed (Bokwa and Skowera 2008, Kozyra and Górski 2008, Szwejkowski et al. 2008, Banaszkiewicz et al. 2009, Bochenek et al. 2012, Czarnecka and Nidzgorska-Lencewicz 2012). Many authors have paid attention to a tendency towards precipitation changes; however, there was a lack of a significant statistical trend in the second half of the XX century. The results of this study, concerning the changes of the sum of precipitation, coincide with the results determined by Degirmendžić et al. (2004) and Czar- necka and Nidzgorska-Lencewicz (2012). Research data concerning the significant growth of the number of the days with precipitation confirm the observations of Bochenek (2012), who stated that in the warm half of the years 1971-2010, the number of days with precipitation greater than $20 \mathrm{~mm}$ increased in Szymbark; however, in the cool half of the year a rise of the number of days with precipitation from 0.1 up to $5 \mathrm{~mm}$ was noted. The results presented here, as well as by other authors, pay attention to the need of further research concerning the changes of the structure of precipitation in Poland. The increases in the air temperature and the changes of the structure of precipitation have had a decisive influence on crop production. They determine the dates of crop treatments, the distribution of the individual development phases of the plants and their water requirements.

\section{CONCLUSIONS}

1. The rise of the mean annual air temperature in Poland in 1971-2010 in all meteorological stations taken into account in this research was about $0.9^{\circ} \mathrm{C}$ over 10 years. However, the trend of the changes of the monthly temperature is characterised with the strong diversity in the examined period and in the studied stations.

2. A tendency towards an earlier beginning of all thermal seasons was recorded in all meteorological stations. A statistically significant changes of the dates of the beginning of the vegetation season in Koszalin and Olsztyn, the beginning of the intensive vegetation season in the all stations and the beginning of summer in Lublin were confirmed. 
3. As far as the dates of the end of the thermal seasons are concerned, a statistically significant upward trend was confirmed, which suggests that these periods finished later.

4. A statistically significant trend of the sum of the monthly precipitation was observed in August in Koszalin, but a seasonal precipitation trend was noted only in the cool season of the year in Poznań.

5. A distinct increase of the number of days with precipitation was recorded. Its statistically significant trends of changes were diversified in all stations.

\section{REFERENCES}

BAŃSKI J., BŁAŻEJCZYK K. 2005: Globalne zmiany klimatu i ich wpływ na światowe rolnictwo. In: G. Dybowski (Ed.) Wpływ procesu globalizacji na rozwój rolnictwa na świecie. Program wieloletni 2005-2009. IERiGŻ PIB, Warszawa: 204-231.

BANASZKIEWICZ B., GRABOWSKA K., PANFIL M. 2009: Charakterystyka warunków opadowych Pojezierza Iławskiego i Chełmińsko-Dobrzańskiego w latach 1951-2000. Acta Agrophysica 13(3): 575-585.

BARTOSZEK K., BANASIEWICZ I. 2007: Agrometeorologiczna charakterystyka okresu wegetacyjnego $2005 \mathrm{w}$ rejonie Lublina na tle wielolecia 1951-2005. Acta Agrophysica 9 (2): 275-283.

Biuletyn Państwowej Służby Hydrologiczno-Meteorologicznej. 2010-2012. Instytut Meteorologii i Gospodarki Wodnej, Warszawa.

BOCHENEK W. 2012: Ocena zmian warunków opadowych na stacji naukowo-badawczej IGiPZ PAN w Szymbarku w okresie 40 lat obserwacji (1971-2010) i ich wpływ na zmienność odpływu ze zlewni Bystrzanki. Woda - Środowisko - Obszary Wiejskie (IV-VI) 12, 2(38): 29-44.

BOKWA A., SKOWERA B. 2008: Wpływ rzeźby i użytkowania terenu na strukturę opadów atmosferycznych w okolicach Krakowa (1971-2005). Infrastruktura i Ekologia Terenów Wiejskich 5: 51-62.

CZARNECKA M., NIDZGORSKA-LENCEWICZ J. 2012: Wieloletnia zmienność sezonowych opadów w Polsce. Woda - Środowisko - Obszary Wiejskie (IV-VI) 12, 2(38): 45-60.

DEGIRMENDŽIĆ J., KOŻUCHOWSKI K., ŻMUDZKA E. 2004: Changes of air temperature and precipitation in Poland in the period 1951-2000 and their relationship to atmospheric circulation. Int. J. Climatol. 24: 291-310.

GÓRSKI T., KOZYRA T. 2011: Agroklimatyczna norma średniej temperatury powietrza $\mathrm{w}$ Polsce na lata 2011-2020. Pol. J. Agr. 5: 21-28.

HIRSCH R.M., SLACK J.R., SMITH R.A. 1982: Techniques of trend analysis for monthly water quality data. Water Resour. Res. 18: 107-121.

KOŁODZIEJ J., LINIEWICZ K., BEDNAREK H. 2003: Opady atmosferyczne w okolicy Lublina a potrzeby opadowe roślin uprawnych. Annales Universitatis Mariae Curie-Skłodowska Lublin - Polonia, sec. E, 58: 101-110.

KOŁODZIEJ J., WĘGRZYN A. 2004: Zróżnicowanie czasu trwania okresu wegetacyjnego w Obserwatorium Agrometeorologicznym w Felinie w pięćdziesięcioleciu 1951-2000. Annales Universitatis Mariae Curie-Skłodowska Lublin - Polonia, sec. E, 59: 869-880.

KOZYRA J., GÓRSKI T. 2008: Wpływ zmian klimatycznych na uprawy w Polsce. In: Zmiany klimatu, a rolnictwo i obszary wiejskie. Fundacja na rzecz Rozwoju Polskiego Rolnictwa, Warszawa: 36-40.

KOŻUCHOWSKI K., DEGIRMENDŽIĆ J. 2005: Contemporary changes of climate in Poland: trends and variation in thermal and solar conditions related to plant vegetation. Pol. J. Ecol. 53, 3: 283-297.

KUNDZEWICZ Z.W., JUDA-REZLER K. 2010: Zagrożenia związane ze zmianami klimatu. Nauka 4: 69-76.

KUNDZEWICZ Z.W., KĘDZIORA A. 2010: Zmiany klimatu i ich wpływ na środowisko i gospodarkę (obserwacje i projekcje). Studia i Raporty IUNG-PIB, 19: 115-132.

MICHALSKA B. 2011: Tendencje zmian temperatury powietrza w Polsce. Prace i Studia Geograficzne 47: 67-75.

OLECHNOWICZ-BOBROWSKAB.,WOJKOWSKI J. 2006: Okresy termiczne w południowej 
części Wyżyny Krakowsko-Częstochowskiej (1991-2000). Klimatyczne Aspekty Środowiska Geograficznego. IG i GP UJ, Kraków: 52-61.

OLSZEWSKI K., ŻMUDZKA E. 2000: Variability of the vegetative period in Poland. Miscellanea Geographica 9: 59-70.

SKOWERA B., KOPEĆ B. 2008: Okresy termiczne w Polsce południowo-wschodniej (1971-2000). Acta Agrophisica 162, 12(2): 517-526.

SZWEJKOWSKI Z., DRAGAŃSKA E., BANASZKIEWICZ B. 2008: Scenariusze warunków agroklimatycznych okolic Olsztyna w perspektywie spodziewanego globalnego ocieplenia w roku 2050. Acta Agrophysica 12(2): 543-552.

USTRNUL Z., CZEKIERDA D. 2007: Wpływ wskaźnika Oscylacji Północnoatlantyckiej na średnią temperaturę powietrza $\mathrm{w}$ różnych skalach przestrzennych. Wahania klimatu w różnych skalach przestrzennych i czasowych. IG i GP UJ, Kraków: 74-84.

ŻMUDZKA E., DOBROWOLSKA M. 2001: Zmienność termicznego okresu wegetacyjnego w Polsce w drugiej połowie XX wieku. Prace i Studia Geograficzne 29: 127-136.

ŻMUDZKA E. 2004: Tło klimatyczne produkcji rolniczej w Polsce w drugiej połowie XX wieku. Acta Agrophysica 3(2): 399-408.

ŻMUDZKA E. 2009: Współczesne zmiany klimatu Polski. Acta Agrophysica 13 (2): 555-568.

ŻMUDZKA E. 2012. Wieloletnie zmiany zasobów termicznych w okresie wegetacyjnym i aktywnego wzrostu roślin w Polsce. Woda - Środowisko - Obszary Wiejskie (IV-VI) 12, 2(38): 377-389.

Streszczenie: Zmiany warunków termiczno-opadowych $w$ Polsce w latach 1971-2010. W pracy przedstawiono zmiany warunków termiczno-opadowych na obszarze Polski w latach 1971-2010 na podstawie danych z sześciu stacji meteorologicznych (Koszalin, Olsztyn, Poznań, Lublin, Opole i Kraków). Dane te dotyczyły średniej miesięcznej temperatury powietrza, miesięcznych sum opadów oraz liczby dni w miesiącu $\mathrm{z}$ opadem. Na podstawie analizy trendów zmian wykorzystanych w opracowaniu elementów meteorologicznych stwierdzono wzrost średniej rocznej temperatury powietrza o ok. $0,9^{\circ} \mathrm{C}$ w ciagu 10 lat we wszystkich miejscowościach. Zauważono, że trendy zmian średniej miesięcznej temperatury powietrza charakteryzowały się zróżnicowaniem czasowym i przestrzennym. $\mathrm{Na}$ skutek wzrostu temperatury zmienił się przebieg dotychczasowych dat początku i końca oraz długości okresów termicznych: gospodarczego (OG), wegetacyjnego (OW), intensywnej wegetacji (OIW) oraz dojrzewania, czyli termicznego lata $(\mathrm{OD} / \mathrm{L})$. Zauważono tendencje do wcześniejszego rozpoczynania się tych okresów. Istotne statystycznie zmiany stwierdzono w przypadku okresów: wegetacyjnego w Koszalinie i Olsztynie, intensywnej wegetacji na wszystkich stacjach, a termicznego lata tylko w Lublinie. Zauważono również coraz późniejsze kończenie wymienionych okresów, a istotne statystycznie trendy stwierdzono w przypadku dat końca okresów: dojrzewania (termicznego lata) na wszystkich stacjach oprócz Opola, intensywnej wegetacji w Poznaniu i Lublinie oraz wegetacji w Lublinie i Opolu. Sezonowe i miesięczne sumy opadów w latach 1971-2010 cechowały się cyklicznością. Istotne trendy wzrostowe stwierdzono tylko w przypadku miesięcznych sum opadów w sierpniu w Koszalinie i sum opadów półrocza chłodnego w Poznaniu. Więcej dni z opadem zauważono na wszystkich stacjach uwzględnionych w opracowaniu, ale istotność statystyczna trendów zmian była zróżnicowana przestrzennie. Zmiany warunków termiczno-opadowych przejawiające się m.in. we wzroście temperatury, zmianach długości okresów termicznych oraz wzroście częstości opadów stanowią ważną informację dla sektora rolniczego o zmieniających się warunkach uprawy roślin.

Stowa kluczowe: opady atmosferyczne, liczba dni $\mathrm{z}$ opadem, temperatura, okresy termiczne, trendy

\section{MS. received in May 2014}

\section{Authors' address:}

Barbara Skowera

Uniwersytet Rolniczy w Krakowie

Wydział Inżynierii Środowiska i Geodezji

Katedra Ekologii, Klimatologii i Ochrony

Powietrza

Al. Mickiewicza 24/28, 30-059 Kraków, Poland e-mail: rmskower@cyf-kr.edu.pl 